\title{
US initiates chip war with Japan
}

- US threatens $\$ 300$ million increase in tariffs

- Japan pleads innocence of agreement breach - Third-market 'dumping' of chips continues

Washington

IN what could be the first salvo of an open trade war, the United States last week announced that it would raise tariffs on as much as $\$ 300$ million in imports from Japan as a response to what are held to be violations of the agreement on semiconductor trade signed last summer. The tariffs will not be applied to semiconductors, but to other electronic products for which US companies still hold sizeable market shares.

President Ronald Reagan announced the sanctions on Friday 27 March, the day after his Economic Policy Council met to present him with options. Reagan accused Japan of failing to enforce "major provisions of the agreement" on semiconductors, and sided with US semiconductor manufacturers who have accused Japanese manufacturers of selling chips below cost to third countries for transhipment to the United States as a way around potential US duties. Such 'dumping' is prohibited by the trade agreement, but many agree it is difficult if not impossible to enforce. US manufacturers also say that they see no evidence of improved access to Japanese markets as promised by the semiconductor agreement.

Discontent over Japanese willingness to purchase US-made products was substantially augmented after a visit by a US trade delegation to Japan in February. Makoto Kuroda, vice-chief of MITI, the Ministry of International Trade and Industry, told the visiting delegation at a luncheon that attempts to sell US supercomputers to Japanese government agencies or universities would be futile. This comment caused a furore in US government circles, and apparently led to increased impetus on the government's behalf to retaliate against Japan.

A list of products to be covered by the tariffs will be published this week in the Federal Register. There will be a 14-day period for comment before a final list is announced. Tariffs will be as high as 100 per cent of import cost. A preliminary list includes televisions, radios, refrigerators, air conditioners, electric motors, pocket calculators and computer disk drives and central processing units.

At a meeting in Japan on 28 January, US officials warned that if third-market dumping did not stop in 30 days and market access improve in 60 days, the United States would "take appropriate steps to enforce the agreement". But Commerce Department data indicated that dumping continued a month after the meeting.

US figures showed that dynamic random access memory chips were being sold at an average of 59.4 per cent below "fair price", and erasable programmable readonly memory chips were selling at $63.6 \mathrm{per}$ cent below their fair price.

Congress seems ready to support the administration's retaliatory moves against Japan. On 19 March, the Senate passed by 93 votes to none a resolution calling on the president to take action on violations of the US-Japan semiconductor agreement. Members of the House of Representatives have indicated similar sentiments.

Recent Japanese efforts to reduce chip production and prevent dumping are described as "encouraging" by the president. But he is insisting that the trade sanctions will not be lifted until there is evidence that Japan is vigorously enforcing the semiconductor agreement. Joseph Palca

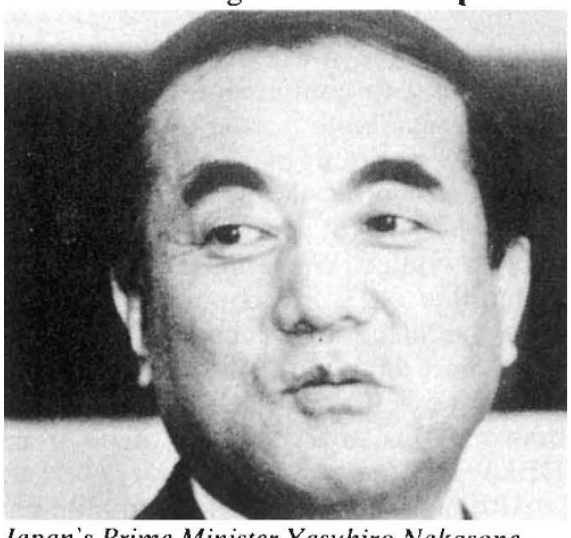

Japan's Prime Minister Yasuhiro Nakasone.

\section{Japan dismayed by US retaliation}

Tokyo

THE trade sanctions announced last week by the United States against Japan were greeted with dismay by Japanese officials, who insist that they have been adhering to the terms of the agreement on semiconductors signed on 31 July last year. The Ministry of International Trade and Industry (MITI) says that Japan has taken significant steps in the past few months both to encourage foreign chip imports and to tackle the root of what it sees as the problem - oversupply and rock-bottom prices.

The present problems in the chip trade can be traced back to 1984, when Japanese electronics companies invested massively in plant and equipment for memory-chip production. Oversupply and fierce com- petition drove down prices, but Japan was able to capture 80 per cent of the world market.

The agreement was intended to protect the embattled US semiconductor industry as well as to provide access for US companies to the Japanese market. The provision in the agreement that chip prices in third-country markets should not be lower than those held to be fair for direct sales between Japan and the United States, was intended to prevent low-priced sales through intermediaries, but provoked many other companies to complain that they were being denied access to cheap Japanese supplies.

The immediate effect of the agreement in Japan was that prices plummeted whereas Japanese exports to third countries (in Latin America, South-East Asia and Europe) doubled as trading companies saddled with chips they could not sell to the United States unloaded their chips elsewhere at reduced prices. Many of these cheap chips have nevertheless found their way to the United States.

In mid-February, as US criticisms of Japan's failure to meet the agreement mounted, MITI instructed Japanese chipmakers to reduce production by 20 per cent in the remainder of the first quarter (January-March). But US complaints have continued unabated, and last week (23 March) MITI ordered a further 11 per cent cut in production in the next quarter.

Also, in early March, MITI set up the International Semiconductor Cooperation Center to promote the import of foreign chips, and Hajime Tamura, minister of international trade and industry, appealed to major Japanese semiconductor users to buy more foreign chips. But only Japanese users and one French company have so far joined the centre, even though the annual subscription fee is a mere Y200,000 $(\$ 1,450)$. US exporters have shunned the centre on the grounds that it is controlled by their competitors.

According to MITI, Tamura wrote to US government officials on 28 March describing these developments and suggesting a joint US-Japan study of the thirdmarket problem. MITI claims that the prices as low as $\$ 1.8$ a chip in South-East Asia are caused by Korean and even US producers selling at lower than economic prices so as to expand their market share. MITI also says that the supply of cheap chips from Japanese trading companies has now almost dried up. One MITI official has even suggested to the Japanese press that the recent disclosure of chip dumping in Hong Kong by the Oki Electric Industry Company may be the result of a subterfuge, or 'sting' organized by the United States.
David Swinbanks 